Gi respons på artikler gjennom artiklenes kommentarfelt på tidsskriftet.no.

Innleggene publiseres fortløpende på Tidsskriftets nettside og et utvalg

av innleggene publiseres også i papirutgaven i spalten «Brev til redaktøren».

Redaksjonen forbeholder seg retten til å foreta redaksjonelle endringer.

Forfattere av vitenskapelige artikler har tilsvarsrett, jf. Vancouver-gruppens regler.

\section{Re: Hvorfor er tilbakemelding så vanskelig?}

«Det må utvikles en kultur for ros, råd, kritikk og samtale», skriver Petter Gjersvik (1). Jeg kunne ikke vært mer enig, og jeg er glad for at evaluering blir satt på dagsorden.

Jeg mener at evaluering er helt sentralt i å bli den beste versjonen av deg selv, og derav en bedre lege. Det handler om så mye mer enn å bli evaluert på faglige prestasjoner. Det handler om hvordan man jobber sammen med andre mennesker - noe en lege skal gjøre resten av karrieren. Videre handler det også om å bli bedre kjent med seg selv gjennom selvrefleksjon. Hvordan skal man kunne utvikle seg uten å vite hva man kan forbedre seg på? Hvordan bli klar over sin egen gode eller dårlige oppførsel hvis ingen sier ifra?

På medisinstudiet $\mathrm{i}$ Trondheim blir studentene delt inn i grupper for problembasert læring (PBL) fra dag én. Halvveis i semesteret står evaluering av gruppen og hvert enkel individ på timeplanen. Her har veilederne et stort forbedringspotensial, nemlig å bruke den tiden som faktisk er satt av til evaluering. Det er fort gjort $i$ en stresset hverdag at man ikke prioriterer dette. Muligheten til å sette søkelyset på evaluering fra starten av studiet er der, men viljen til å se at det er like viktig som fagstoff, ser ut til å mangle.

Jeg vil til slutt påpeke at det finnes god kultur for evaluering i norsk helsevesen. Som sommervikar på en avdeling ble jeg møtt av overleger som på hvert morgenmøte ga ris og ros. Det var åpenhet om hvilke valg du hadde gjort, som var riktige, og hvilke valg du kunne gjøre bedre neste gang. Jeg fikk tilbake både innkomstjournaler og epikriser med kommentarer og forslag. Det er noe av det mest utfordrende jeg har opplevd, men jeg har aldri lært så mye som i løpet av de månedene, både faglig og om meg selv.

Ansvaret ligger også hos nyutdannede leger. Vi må våge å utfordre oss selv, være mer kreative og modige. Slik at de som kommer etter oss, ser på evaluering som en naturlig del av hverdagen.

\section{Ane-Kristine Finbråten \\ ane.finbraten@gmail.com}

Ane-Kristine Finbråten (f. 1986) er stipendiat ved Institutt for laboratoriemedisin, barne- og kvinnesykdommer, Norges teknisk-naturvitenskapelige universitet.

Ingen oppgitte interessekonflikter

Litteratur
1. Gjersvik P. Hvorfor er tilbakemelding så vanskelig? Tidsskr Nor Legeforen 2014;
134: 591.

\section{Re: En gravid kvinne med oppkast og pustebesvær}

I Tidsskriftet nr. 4/2014 presenterer Hatle og medarbeidere en lærerik kasuistikk om en gravid kvinne med akutt pustebesvær og akalasi (1).

Pasienten ble innlagt med mistanke om akutt lungeemboli. Det ble gjort ekkokardiografi uten at det ble påvist lungeemboli. Pulmonal CT-angiografi, eventuelt kombinert med CT-venografi, er anerkjent som primær metode ved utredning av mistenkt lungeemboli (2). Ekkokardiografi gir ikke optimal diagnostikk, siden negativ undersøkelse ikke utelukker lungeemboli. Embolier på lappe-, segment-, eller subsegmentalt nivå fremstilles ikke på ekkokardiografi. Metoden er imidlertid aktuell for å evaluere høyre ventrikkels funk- sjon, trykk i lille kretsløp og for å vurdere differensialdiagnoser hos kritisk syke pasienter (3).

Det er ikke angitt hvilke overveielser som førte til at man valgte ikke å utrede videre med CT, men vi antar at strålehygieniske hensyn inngikk i vurderingen. Imidlertid er det ikke holdepunkter for strålerelaterte fosterskader etter diagnostiske radiologiske prosedyrer (4). Det kan foreligge økt risiko for misdannelser ved fosterdoser på mer enn 100 mGy. Pulmonal CT-angiografi innebærer en stråledose til foster i størrelsesorden $0,3 \mathrm{mGy}$. Risikoen for å overse potensielt livstruende maternell sykdom må derfor veie tyngre enn strålehygieniske hensyn til fosteret. Dette innebærer at utredning av mistenkt lungeemboli hos gravide bør gjøres på grunnlag av de samme overveielsene og etter samme algoritmer som hos ikke-gravide $(4,5)$. Ventilasjons-perfusjons-scintigrafi anbefales ikke som primær metode fordi metoden er lite spesifikk, i tillegg til at den innebærer høyere stråledose enn CT (4).

Vi mener derfor at det hadde vært naturlig å følge opp med CTangiografi i det beskrevne tilfellet. I stedet ble det gjort gjentatte røntgen thorax, formodentlig for å utelukke andre årsaker til brystsmerter enn lungeemboli. Røntgen thorax har ingen definert plass i utredning av lungeembolisme (6) fordi det er en relativt grov screeningundersøkelse som verken er spesifikk eller sensitiv. Om man i denne situasjonen hadde supplert røntgenundersøkelsen med CT-undersøkelse, ville én og samme undersøkelse trolig avklart både om det forelå lungeembolisme og signifikant patologi i lungeparenkym, skjelett og mediastinum.

Diagnosen akalasi ble mistenkt etter gastroskopi, og på dette stadiet i utredningen ble det gjort MR oesophagus. Igjen antar vi at strålehygieniske hensyn ble vektlagt fordi MR til forskjell fra CT ikke innebærer ioniserende stråling. MR ga neppe bedre diagnostikk av oesophagus enn CT ville ha gitt. CT ville i tillegg fremstilt skjelett, lungeparenkym og mediastinale strukturer raskere og trolig bedre enn MR. Flere dagers forsinket diagnostikk kunne ha vært unngått hvis det var blitt gjort CT thorax eller pulmonal CT-angiografi tidlig i forløpet. Redsel for skadelige effekter av ioniserende stråler er ubegrunnet i de dosenivåene vi opererer med innen diagnostisk radiologi, og må ikke stå i veien for at de beste diagnostiske metodene benyttes ved utredning av potensielt livstruende sykdom.

\section{Trond Mogens Aaløkken \\ trond.mogens.aalokken@rikshospitalet.no \\ Georg Mynarek \\ Anne Catrine T. Martinsen}

Trond Mogens Aaløkken (f. 1957) er thoraxradiolog og enhetsoverlege ved Radiologisk avdeling, Oslo universitetssykehus, Rikshospitalet Ingen oppgitte interessekonflikter.

Georg Mynarek (f. 1961) er indremedisiner og thoraxradiolog og overlege ved Radiologisk avdeling, Oslo universitetssykehus, Rikshospitalet. Ingen oppgitte interessekonflikter.

Anne Catrine T. Martinsen (f. 1974) er fysiker og seksjonsleder på Intervensjonssenteret, Oslo universitetssykehus og førsteamanuensis på Fysisk institutt, Universitetet i Oslo.

Ingen oppgitte interessekonflikter.

\section{Litteratur}

1. Hatle H, Erwied BM, Lode I et al. En gravid kvinne med oppkast og pustebesvær Tidsskr Nor Legeforen 2014: 134: 426-9. 